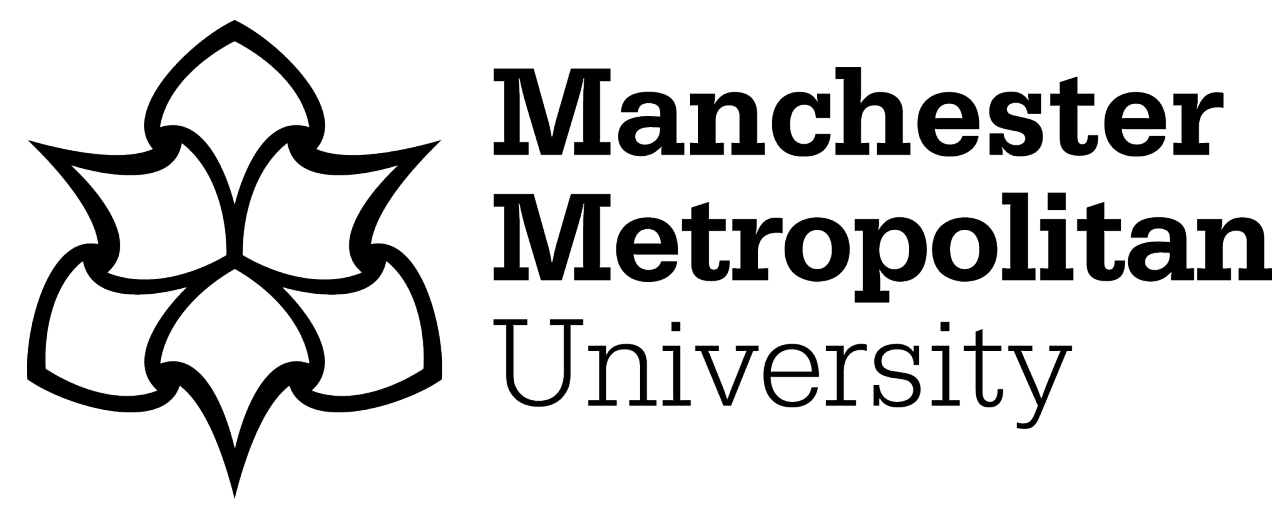

Pereira, CM, Anholon, R, Rampasso, IS, Quelhas, OLG, Leal Filho, W and Santa-Eulalia, LA (2020) Evaluation of lean practices in warehouses: an analysis of Brazilian reality. International Journal of Productivity and Performance Management, 70 (1). pp. 1-20. ISSN 1741-0401

Downloaded from: https://e-space.mmu.ac.uk/625663/

Version: Accepted Version

Publisher: Emerald

DOI: https://doi.org/10.1108/IJPPM-01-2019-0034

Please cite the published version 


\title{
Evaluation of Lean practices in Warehouses: An analysis of Brazilian reality
}

Caroline Morito Pereira, Rosley Anholon, Izabela Simon Rampasso, Osvaldo L.G. Quelhas, Walter Leal Filho, Luis Antonio Santa-Eulalia

International Journal of Productivity and Performance Management

https://www.emerald.com/insight/content/doi/10.1108/IJPPM-01-2019-

$\underline{0034 / \text { full/html }}$

\begin{abstract}
Purpose: This article aims to investigate the most applied lean warehouse practices in Brazilian warehouses.

Design/methodology/approach: To perform this research, three phases were conducted: a literature review, a multiple case study and an analysis of lean warehouses practices implementation by an engineering committee. Thus, both qualitative and quantitative approaches were used. Additionally, the study has an applied nature, with an exploratory and descriptive character.
\end{abstract}

Findings: Results showed that, regardless of the type of criterion used, the most implanted practices are those that do not involve investments in technology. On the other hand, practices like RFID and Cross Docking systems were not found in any of the operations, which shows numerous possibilities for improvement.

Originality/value: The main contribution of this article is to initiate a debate about the management and productivity of Brazilian warehouses, a theme still little explored by the academic community despite the importance that the logistic scenario represents for Brazil as an emerging country and leader in Latin America, participating actively in several global supply chains.

Keywords: Lean; Process management; Logistics industry.

Article Classification: Research paper

\section{Introduction}

Competitiveness among companies is continuously growing and it is reflected in supply 
chains, which must operate in an increasingly leaner way without compromising the quality of product distribution (Ballou, 2010; Liu and Lee, 2018; Oláh et al., 2018; Tortorella et al., 2018). Directly related to this scenario are storage operations that, if properly managed, can positively contribute to a better business performance (Dharmapriya and Kulatunga, 2011; Laosirihongthong et al., 2018; Staudt et al., 2015).

For Bowersox et al. (2013), the reality reported above was not always present. For a long time, topics such as the location strategy of warehouses in the supply chain and studies on more efficient techniques of material handling were neglected by managers and by the literature, which disregarded their potential contribution to business competitiveness. The same authors state, however, that this was in the past and currently we know that the storage activities, if properly managed, can add greater value to the customer. Ben Moussa et al. (2019) corroborate with this affirmation, highlighting the importance of warehouses for supply chains competitiveness.

Phogat (2013) corroborates this thinking by stating that storage activities can be characterized as strategic elements in the search for differentiation compared to other competitors. By reducing existing waste in these activities, you can add value to the customer and improve the whole supply chain (Baker and Canessa, 2009). In general, storage activities represent a large percentage of logistics costs (Buonamico et al., 2017; Frazelle, 2002); thus investigations in this sector may bring promising results.

A relevant issue to be addressed is the barriers faced by organizations to enhance warehousing performance. Among these barriers, the difficulties related to technologies advancements implementation, increase of activities efficiency and requirements for implementing methods to enable improvements in warehousing performance (Lim et al., 2013; Luo et al., 2019; Ben Moussa et al., 2019). 
Within this scenario of adding value and minimizing waste in storage activities, the principles of lean production (free of waste) have begun to gain greater visibility within supply chains in recent years. As in the original philosophy of lean production, it looks for waste reductions and improved operational performance, adding greater customer value (Alshahrani et al., 2018; Dehdari, 2013; Liu et al., 2017; Sharma and Shah, 2016; Sobanski, 2009; Tortorella et al., 2018; Villarreal et al., 2017).

Garcia (2003) argues that lean storage can be characterized as a major differential for warehouses, since the adoption of lean principles and tools optimizes the flow of storage and improves the level of customer service (de Visser, 2014). These results, however, will only be achieved with great commitment and dedication, since they require actions such as accurate inventory control, shorter response times and service to a greater variety of products to customers, with more quality and fewer errors (Mustafa, 2015).

Despite the great importance and relevance of lean techniques for storage activities, few papers have been published about this topic and there are several plausible research gaps to be explored (Buonamico et al., 2017; Mustafa et al., 2013). For Bozer (2012), the use of lean in warehouses does not present the same level of maturity of the application observed in the factory environment, and there is ample possibility for researches that develop new tools, models, etc. In this context, the evaluation of the degree of implementation of lean techniques in storage centers becomes the first step in the construction of new scientific knowledge in the area.

The challenges of implementing lean in warehouses also need to be related to national contexts. Developed and developing countries present different scenarios. In this sense, emerging countries can present more challenges for companies to implement lean. Economic uncertainty, for example, can be a reason for companies to do not reduce their inventory levels. Focusing on Brazilian scenario, the low education level of a 
considerable proportion of workers and the reduced cost of workforce can prejudice lean practices implementation (Tortorella et al., 2018).

In order to contribute to reducing these research gaps, the present article investigates the most applied lean warehouse practices in Brazilian warehouses. To do so, we performed a literature review and identified 13 practices associated with lean warehousing. Subsequently, 10 Brazilian warehouses were evaluated by an engineering committee and data was analyzed using TOPSIS (Technique for Order of Preference by Similarity to Ideal Solution) techniques for different criteria.

In addition to this introduction, this article presents 4 more sections. Section 2 is devoted to literature review. Section 3 presents the methodological procedures. Section 4 presents the results and associated debates and, finally, Section 5 outlines the conclusions and final considerations.

\section{Theoretical background}

\subsection{Lean thinking and its correlation in storage environments}

Warehouses play a fundamental role in supply chains, defining to a large extent the companies' success in terms of competitiveness when evaluating costs and levels of customer service (Frazelle, 2002). Despite their costs, warehouses act as a buffer between

supply and demand variability, making them necessary elements in contemporary supply chains (Gu et al., 2007).

As a base activity, warehouses perform material reception, storage, order picking and shipping (de Koster et al., 2007). According to Baker and Halim (2007), the receipt process is classified by the arrival of Stock Keeping Unit (SKU) in the warehouse, updating of inventory records and inspection to verify quantity divergences and quality inconsistencies. Then, the transfer of these SKUs to the storage areas occurs and there 
may be reserved areas or areas dedicated to the collection of items, in which they are available in an accessible way for the order separation processes.

These activities result in high warehouse expenses and create a challenge in cost reductions and maintenance of high customer quality levels. Factors such as e-commerce, supply chain collaboration, globalization, technologies, and new management techniques, such as lean methodologies and practices, have led warehouses to success, driving them to more accurate inventory controls, shorter customer response times and greater variety of products delivered (Franzke et al., 2017; Gu et al., 2007).

There is a contradiction between lean thinking within a storage environment, since the lean principles in an ideal scenario govern a flow of value free of waste, without inventories in process and with a production pulled in accordance with the needs of customers (Bozer, 2012; Garza-Reyes et al., 2018; Ponte et al., 2018). For Swart (2015), storing is basically an activity that does not add value, but it is extremely necessary to ensure that customer needs are attended to at the correct time, as mentioned by Frazelle (2002).

In this context, there is a need to leverage warehousing operations that involve time and cost, by eliminating waste as much as possible and optimizing activities that add value to the customer (Sharma and Shah, 2016). Lean warehouse ensures deliveries with quality and accuracy to customers due to increased efficiency and productivity gained from lean practices and principles. And although there is no precise definition of a lean warehouse, there are some concepts and practices that, when applied, power the functions of a warehouse (Sharma and Shah, 2016). These concepts discuss all the organizational, operational and human characteristics related to lean storage.

\subsection{Lean warehousing related models and roadmap}


Some authors in the literature have sought to develop models based on these concepts and practices that help warehouses to achieve competitive gains by adding value to activities and eliminating waste in order to maintain a lean operation. In their work, Gunasekaran et al. (1999) developed a conceptual model to improve the effectiveness of warehousing operations and achieve cost reductions with high level of customer service. In this model, the authors apply lean thinking concepts such as JIT, pulled flow, minimum lot, waste reduction and continuous improvement, aiming to reduce inventories in process, process times and to guarantee greater operational fluidity.

Another model found in the literature is presented by study of Mustafa (2015), who developed a theoretical model about lean storage based on a detailed literature review, lean production concepts, principles of lean thinking and the model of Gunasekaran et al. (1999) presented previously. Mustafa (2015) performed a preselection of the most important lean concepts in terms of applicability within warehouses, in order to reflect an organizational system that covers all related aspects. Within each concept of the model, the author discusses lean tools applicable to each stage of the storage process. This model is composed of five constructs: Waste Control, Flow Management, Quality Assurance, Human Resources Management, and Continuous Improvement.

Roadmap propositions are also presented in the literature regarding lean in warehouses. After showing the impact of the seven wastes (Defects, Unnecessaryinventory, Overproduction, Unnecessary-motion, Waiting, Transporting, and Inappropriate-processing) on warehouse operational performance, Salhieh et al. (2019) developed a roadmap to guide practices to reduce wastes in warehouses.

\subsection{Lean warehousing evaluation}


Sobanski (2009) developed a detailed evaluation model of lean concepts within storage environments, aiming at measuring the application of each principle and corresponding practice in different warehouses. This assessment was carried out in twenty-five warehouses, with operations located in the United States, Canada, Germany and Holland in the automotive, consumer goods and technology sectors.

In the same line of reasoning, Buonamico et al. (2017) proposed a fuzzy logicbased metric to evaluate lean warehousing. For the proposed Warehouse's Global Leanness, seven key performance indicators were assessed: Just in Time; Waste elimination; Perfection, zero defects and quality; Lean tools application; Cross-functional teams and empowerment; Continuous improvement; Supplier management. A total of eighteen sub-indicators were derived from these indicators to compose the proposed tool.

Also focusing on lean warehousing, in Abushaikha et al. (2018), the authors conducted a research to measure the impact of warehouse waste reduction practices on companies' performance, with a sample of Middle Eastern companies. They verified that operational and distribution performances improved with the mentioned practices, however, business performance was not directly affected by the practices.

\subsection{Lean warehousing practices}

According to Van Den Berg (2007), Gu et al. (2007) and de Koster et al. (2007), it is important to note that lean practices and concepts, if correctly applied in warehousing processes, offer levels of services that are competitive in relation to lower costs and high quality, guaranteeing competitive advantage for the warehouse or the whole supply chain.

In this context and observing the importance of providing a view of the lean practices applied in warehouses, Table 1 summarizes the practices mentioned in the literature. 


\section{Table 1 position.}

\section{Methodological procedures}

The main steps of this work are: systematic literature review about lean warehouse, case studies performed in ten warehouses in order to detail storage operations, engineering committee meeting to assess each of the 13 practices in warehouses, application of the TOPSIS technique for 3 different criteria to order the practices according, analysis of the results and associated debates. Thus, both qualitative and quantitative approaches were used. Additionally, the study has an applied nature, with an exploratory and descriptive character (Gil, 2010; Hair et al., 2005). The data for all research phases (case studies, interviews and survey) were collected from June 2017 to February 2018. These steps are described in detail afterwards.

The systematic review of the literature (Phase 1) was based mainly on papers published in renowned scientific databases, including Science Direct, Springer, Emerald Insight, Scopus, Scielo. Relevant doctorate thesis were also considered due to the previously mentioned lack of research on this thematic. The publications were chosen using the keywords 'lean warehouse' associated with 'distribution center', 'warehouses', 'lean manufacturing" and 'lean warehouse"'. A total of 47 articles were used to develop Table 1. The practices were identified and organized using the models presented by Gunasekaran et al. (1999), Mustafa (2015) and Sobanski (2009). The practices P3, P5 and P10 were present in seven articles; P1, P2, P4, P8, P1 1 and P13 were found in six articles; P6, P7, P9 were in four articles; and P12 was present in three articles.

Next, case studies were performed in 10 warehouses (phase 2) to provide a basis for the engineering committee analyses. The case studies were used as an overview of Brazilian warehouse scenario for the mentioned committee. Although the case studies 
selection was non-aleatory, the analysed companies are relevant in their sectors and are considered benchmark. Thus, the analysis of them can provide an interesting overview of a sample of the most advanced lean warehouses in Brazil. Additionally, it is important to highlight that the findings of this study are exploratory and provide a relevant contribution to understand lean warehousing in Brazilian context.

The storage operations and practices were detailed through visits, documents analysis (meeting minutes, reports of operational improvements performed, and project schedules to be developed) and interviews with the warehouses' managers. The interview guide is presented in Appendix 1.

The engineering committee was composed of three lean warehouse engineers, with a large experience with improvement projects. All the members of this committee are engineers and work as consultants for the warehouses analysed. This committee was restricted since every member need to be qualified to properly answer the items and need to know the warehouses analysed.

Each engineer evaluated the operations of 10 warehouses considering the 13 practices listed (phase 3). The practices were evaluated considering a scale of 1 to 5 , where note 1 reflects that the practice is not applied in the warehouses and the note 5 reflects that the practice is fully applied. At the end, the average of the scores given for each practice in each center was calculated.

Next, the engineering committee defined the three criteria used in TOPSIS analysis and the weights used for them, through a consensus of the team. These criteria were: 'access to consulting services', 'warehouse manager experience time' and 'warehouse revenue'. Table 2 shows the criteria used in each TOPSIS analysis and weights adopted. 


\section{Table 2 position.}

After the tabulation considering criteria mentioned, TOPSIS analysis was performed in order to rank the practices more applied in warehouses (phase 4). The main idea is to verify if the order of the practices changes when considering different criteria. For this ordering, in this research, the engineering committee were asked to score the practices in a scale from 1 (the practice is not applied) to 5 (the practice is totally applied) in each warehouse.

According to Lima Junior and Carpinetti (2015), the TOPSIS technique stands out for its simplicity and ability to evaluate an unlimited number of alternatives and criteria simultaneously. The TOPSIS method was initially proposed by Hwang and Yoon (1981) and is widely used to rank alternatives in order of preference. TOPSIS technique chooses an alternative that is as close as possible to the ideal positive solution and as far as possible from the ideal negative solution (Araujo et al., 2018; Hwang and Yoon, 1981; Kasirian and Yusuff, 2013; Li et al., 2018; Lima Junior and Carpinetti, 2015).

According to Kahraman (2008), the ideal solution is formed considering the best values achieved in the alternatives considered during the criteria evaluations, and the ideal negative solution taking the worst values. It is important to emphasize that no studies were found in the academic literature that approaches TOPSIS as a technique to evaluate lean warehouse practices in Brazilian storage centers.

The application of TOPSIS is performed through successive steps. Table 3 describes the sequence of the steps used in this research. It should be noted that the sequence used and the mathematical representations are the same used by Singh et al. (2016). 


\section{Table 3 position.}

After all the steps have been performed, the hierarchy of the practices is obtained. It is important to emphasize that TOPSIS technique was performed three times to verify if different criteria impact on ranking obtained. Finally, the analysis of the results and associated debates were carried out, characterizing the fifth phase of this research, as explained in the next section.

\section{Results}

In this section a summary will be presented of the information about each warehouse studied and the TOPSIS technique application, allowing us to obtain three different rankings according to the criteria mentioned in Table 2. It is important to remember that, according to the research objective, the case studies served to provide a better foundation for the engineering committee, and they are not presented here in detail. Table 4 illustrates the activity of warehouses, the sector and information about criteria used in the TOPSIS.

Table 4 position.

\subsection{Evaluation performed by Engineering Committee}

Table 5 presents the grades' averages attributed by engineering committee members for each practice.

Table 5 position. 
To attribute grades, each engineer considered the case study performed and the principles and practices of lean warehouse. The averages represented in Table 5 indicate the maturity of each practice at each warehouse from the engineers' point of view.

\subsection{TOPSIS analyses according to the criteria used}

The TOPSIS analyses were performed for the three criteria defined by the engineering committee and based on the method used by Singh et al. (2016) (see Table 3). In the following paragraphs, we present details of the Ideal Positive Solution (vj+), Ideal Negative Solution (vj-), Distance of the Positive Ideal Solution (Si*), Distance of the Ideal Negative Solution ( $\left.\mathrm{Si}^{\prime}\right)$ and the Ranking $\left(\mathrm{Ci}^{*}\right)$ of the 13 lean warehouse practices.

a) Access to consulting services.

The first criteria used was access to consulting services. Tables 6 shows the averages according to access to consulting services.

\section{Table 6 position.}

These averages lead to Positive Ideal Solution $\left(\mathrm{vj}^{+}\right)$of 0.163082018 ; 0.112172829; and 0.079470395; for more than 5 years, 3 to 5 years, and less than 3 years, respectively. In addition, the Negative Ideal Solutions (vj-) are 0.032616404; 0.024037035; and 0.018339322; for more than 5 years, from 3 to 5 years, and less than 3 years, respectively. Table 7 show the TOPSIS calculations for the distances of the Positive Ideal Solution, distances of the Negative Ideal Solutions and Coefficient $\mathrm{Ci}^{*}$ and in Table 8 the ranking obtained by this first criteria is presented.

\section{Table 7 position.}




\section{Table 8 position.}

\section{b) Warehouse manager experience time}

The second criteria used was 'warehouse manager experience time'. Tables 9 shows the averages according to warehouse manager experience time.

\section{Table 9 position.}

These averages lead to Positive Ideal Solution $\left(\mathrm{vj}^{+}\right)$of 00.17710976; 0.10980561; and 0.078688525 ; for more than 5 years, 3 to 5 years, and less than 3 years, respectively. Additionally, the Negative Ideal Solutions (vj ${ }^{-}$) are $0.039068329 ; 0.024706262$; and 0.019672131; for more than 5 years, from 3 to 5 years, and less than 3 years, respectively. Table 10 show the TOPSIS calculations for the distances of the Positive Ideal Solution, distances of the Negative Ideal Solutions and Coefficient $\mathrm{Ci}^{*}$ and in Table 11 the ranking obtained by this second criteria is presented.

\section{Table 10 position.}

\section{Table 11 position.}

c) Warehouse revenue

The third criteria used was 'warehouse revenue'. Tables 12 shows the averages according to warehouse manager experience time. 
Table 12 position.

These averages lead to Positive Ideal Solution $\left(\mathrm{vj}^{+}\right)$of 0.173017936 ; 0.115160974; and 0.07787938; for more than 5 years, 3 to 5 years, and less than 3 years, respectively. In addition, the Negative Ideal Solutions (vj') are 0.039173872; 0.024677352; and 0.017972165; for more than 5 years, from 3 to 5 years, and less than 3 years, respectively. Table 13 show the TOPSIS calculations for the distances of the Positive Ideal Solution, distances of the Negative Ideal Solutions and Coefficient $\mathrm{Ci}^{*}$ and in Table 14 the ranking obtained by this third criteria is presented.

\section{Table 13 position.}

\section{Table 14 position.}

\section{Discussion}

Through the results obtained in the previous section, it is possible to observe that, independently of the criteria used in TOPSIS analysis, the practices allocated in the first and last positions of the ranking vary little. Also, it is possible to highlight that practices that do not involve investments in technologies and automation are in the first positions in terms of application, independently of the criteria used.

Additionally, the most applied practices are related to the organization of warehouse and 5S culture, Structure, use of key performance indicators (KPI) and visual management and the degree of employee involvement and satisfaction.

Generally, these practices in manufacturing environment are considered the bases of lean philosophy (Bellisario and Pavlov, 2018; Rampasso et al., 2019). In this sense, 
the higher application of these practices in warehouses can be considered a promising result, but for a lower maturity level of lean implementation. This finding corroborates with Bozer (2012). According to this author, the use of lean in warehouses does not present the same level of maturity of the application observed in the factory environment, and there is ample possibility for researches that develop new tools, models, etc. The less applied practices are related to RFID systems for inventory management, Cross Docking technique and total production maintenance (TPM) program. The international literature points to RFID technologies as practice applied in distribution centers highlighting the gains in terms of operational efficiency and competitiveness, however, this practice is not observed in the Brazilian reality.

None of the ten warehouses studied apply this technology. The same happens with Cross Docking practice that is cited by the literature but is not used in Brazilian warehouses. In this way, it highlights opportunities for development of the theme for the Brazilian scenario.The results of practices pointed out as less applied can also be related to the literature, since the improvement of warehousing performance presents several challenges. As highlighted by Lim et al. (2013), Luo et al. (2019), and Ben Moussa et al. (2019), technologies advances, enhance of activities efficiency and methods implementation can be characterized as relevant challenges for warehousing. In addition, although the costs related to RFID have been falling in recent years (Moretti et al., 2019), for Brazilian warehouses reality, this technology is still not being widely implemented.

\section{Conclusions}

The literature present few studies on lean warehousing (Buonamico et al., 2017). Additionally, emerging countries may present more difficulties to implement lean in warehousing. And this reality is not different for Brazilian context (Tortorella et al., 
2018). In this context and aiming to contribute to the literature regarding this thematic, this article evaluated lean warehouse practices implementation in ten Brazilian warehouses employing TOPSIS Analysis and experts' opinion (by an engineering committee) using three different criteria.

Regardless of the criteria used on TOPSIS technique, the results showed that the most implanted practices are those that do not demand high technology and that RFID and Cross Docking systems are not used in any operation. The practice of TPM, despite being implemented in some operations, is still at an early stage. The conclusion is that there are still ample possibilities for improvements in the management and operations of Brazilian warehouses when compared to the international scenario.

As a practical implication, this study can be used as a guide for future improvements in Brazilian warehouses. This paper also contributes to the literature, since it provides relevant findings to the field, which is still underexplored. Besides contributing to lean warehousing literature, this research also provides findings regarding Brazilian lean warehouses reality, showing that, although it still needs to improve, practices of lean warehousing can be observed in the country.

\section{Limitations and future research}

Although it has evaluated the operations of ten Brazilian warehouses and considered different sectors and states of the country, the size of the sample is characterized as a limitation of the research. The authors of this article emphasize, however, the exploratory character of this article and aim to contribute with a theme little explored by Brazilian academic community.

As a proposition to future researches, we recommend studies that analyze the reasons why Brazilian warehouses do not use RFID and Cross Docking techniques in 
their operations. These practices were evaluated in a very present way in the academic scenario and returned satisfactory results in terms of productivity and quality of warehouse operations.

\section{References}

Abushaikha, I., Salhieh, L. and Towers, N. (2018), "Improving distribution and business performance through lean warehousing", International Journal of Retail and Distribution Management, Vol. 46 No. 8, pp. 780-800.

Alshahrani, S., Rahman, S. and Chan, C. (2018), "Hospital-supplier integration and hospital performance: evidence from Saudi Arabia", The International Journal of Logistics Management, Vol. 29 No. 1, pp. 22-45.

Araujo, C.A.S., Wanke, P. and Siqueira, M.M. (2018), “A performance analysis of Brazilian public health: TOPSIS and neural networks application”, International Journal of Productivity and Performance Management, Vol. 67 No. 9, pp. 15261549.

Azanha, A., Vivaldini, M., Pires, S.R.I. and Camargo Junior, J.B. de. (2016), "Voice picking: analysis of critical factors through a case study in Brazil and the United States", International Journal of Productivity and Performance Management, Vol. 65 No. 5, pp. 723-739.

Baker, P. and Canessa, M. (2009), "Warehouse design: A structured approach”, European Journal of Operational Research, Elsevier B.V., Vol. 193 No. 2, pp. 425-436.

Baker, P. and Halim, Z. (2007), "An exploration of warehouse automation implementations: cost, service and flexibility issues", Supply Chain Management: An International Journal, Vol. 12 No. 2, pp. 129-138.

Ballou, R.H. (2010), Gerenciamento Da Cadeia de Suprimentos: Planejamento, Organização e Logística Empresarial., 3rd ed., Bookman, São Paulo. 
Bellisario, A. and Pavlov, A. (2018), "Performance management practices in lean manufacturing organizations: a systematic review of research evidence", Production Planning and Control, Taylor \& Francis, Vol. 29 No. 5, pp. 367-385.

Van Den Berg, J.P. (2007), Integral Warehouse Management. The Next Generation in Transparency, Collaboration and Warehouse Management Systems, Management Outlook, Utrecht, Netherland.

Bowersox, D.J., Closs, D.J. and Cooper, M.B. (2013), Supply Chain Logistics Management, 4th ed., McGraw Hill, New York.

Boysen, N., Briskorn, D. and Emde, S. (2017), "Sequencing of picking orders in mobile rack warehouses”, European Journal of Operational Research, Elsevier B.V., Vol. 259 No. 1, pp. 293-307.

Bozer, Y.A. (2012), "Developing and Adapting Lean Tools / Techniques to Build New Curriculum / Training Program in Warehousing and Logistics", Report University of Michigan, No. July, pp. 1-37.

Brintrup, A., Ranasinghe, D. and McFarlane, D. (2010), "RFID opportunity analysis for leaner manufacturing”, International Journal of Production Research, Vol. 48 No. 9, pp. 2745-2764.

Buonamico, N., Muller, L. and Camargo, M. (2017), “A new fuzzy logic-based metric to measure lean warehousing performance", Supply Chain Forum: An International Journal, Taylor \& Francis, Vol. 18 No. 2, pp. 96-111.

Chen, J.C., Cheng, C.H., Huang, P.B., Wang, K.J., Huang, C.J. and Ting, T.C. (2013), "Warehouse management with lean and RFID application: A case study", International Journal of Advanced Manufacturing Technology, Vol. 69 No. 1-4, pp. $531-542$.

Costa, W.A. da S. and Júnior, J.A.G. (2008), "Etapas de implementação de WMS: estudo 
de caso em um varejista moveleiro", GEPROS. Gestão Da Produção, Operações e Sistemas, Vol. 4 No. 4, pp. 101-121.

Dehdari, P. (2013), "Measuring the impact of lean techniques on performance indicators in logistics operations", Measuring the Impact of Lean Techniques on Performance Indicators in Logistics Operations, pp. 1-191.

Dharmapriya, U.S.S. and Kulatunga, A.K. (2011), "New Strategy for Warehouse Optimization - Lean warehousing", International Conference on Industrial Engineering and Operations Management, No. September, pp. 513-519.

Doolen, T.L., Van Aken, E.M., Farris, J.A., Worley, J.M. and Huwe, J. (2008), “Kaizen events and organizational performance: A field study", International Journal of Productivity and Performance Management, Vol. 57 No. 8, pp. 637-658.

Dotoli, M., Epicoco, N., Falagario, M., Costantino, N. and Turchiano, B. (2015), “An integrated approach for warehouse analysis and optimization: A case study", Computers in Industry, Elsevier B.V., Vol. 70 No. 1, pp. 56-69.

Duc, T. Le and Koster, R. De. (2005), “Travel Distance Estimation in Single-block ABCStorage Strategy Warehouses", in Fleischmann, B. and Klose, A. (Eds.), Distribution Logistics: Advanced Solutions to Practical Problems.

Faber, N., de Koster, R. (Marinus) B.M. and van de Velde, S.L. (2002), "Linking warehouse complexity to warehouse planning and control structure", International Journal of Physical Distribution \& Logistics Management, Vol. 32 No. 5, pp. 381395.

Falkowski, P. and Kitowski, P. (2013), “The 5S methodology as a tool for improving organization of production”, PhD Interdisciplinary Journal, pp. 127-133.

Forno, A.J.D., Pereira, F.A., Forcellini, F.A. and Kipper, L.M. (2014), "Value stream mapping: A study about the problems and challenges found in the literature from the 
past 15 years about application of Lean tools", International Journal of Advanced Manufacturing Technology, Vol. 72 No. 5-8, pp. 779-790.

Franzke, T., Grosse, E.H., Glock, C.H. and Elbert, R. (2017), “An investigation of the effects of storage assignment and picker routing on the occurrence of picker blocking in manual picker-to-parts warehouses", International Journal of Logistics Management, Vol. 28 No. 3, pp. 841-863.

Frazelle, E. (2002), Supply Chain Strategy: The Logistics of Supply Chain Management, McGraw-Hill, New Yorl.

Garcia, F.C. (2003), “Applying lean concepts in a warehouse operation”, Iie Annual Conference and Exhibition 2004, No. 1, pp. 2819-2859.

Garza-Reyes, J.A., Villarreal, B., Kumar, V. and Diaz-Ramirez, J. (2018), “A lean-TOC approach for improving Emergency Medical Services (EMS) transport and logistics operations", International Journal of Logistics Research and Applications, Taylor \& Francis, pp. 1-20.

Gil, A. (2010), How to Design Research Projects (Como Elaborar Projetos de Pesquisa), Editora Atlas, São Paulo.

Gopakumar, B., Sundamaram, S., Wang, S., Koli, S. and Srihari, K. (2008), “A simulation based approach for dock allocation in a food distribution center", Simulation Conference, 2008. WSC 2008. Winter, pp. 2750-2755.

Gu, J., Goetschalckx, M. and McGinnis, L.F. (2007), "Research on warehouse operation: A comprehensive review", European Journal of Operational Research, Vol. 177 No. 1, pp. 1-21.

Gunasekaran, A., Marri, H.B. and Menci, F. (1999), "Improving the effectiveness of warehousing operations: a case study", Industrial Management \& Data Systems, Vol. 99 No. 8, pp. 328-339. 
Hair, J., Babin, B., Money, A. and Samouel, P. (2005), Fundamentos de Métodos de Pesquisa Em Administração, Bookman.

Hanchuan, P., Ruifang, W., Hao, D. and Feng, Z. (2013), “The Research of Logistics Cost and Influencing Factors Based on Cross Docking", Procedia - Social and Behavioral Sciences, Elsevier B.V., Vol. 96 No. Cictp, pp. 1812-1817.

Hassan, M.M.D. (2002), “A framework for the design of warehouse layout”, Facilities, Vol. 20 No. 13/14, pp. 432-440.

Heragu, S.S., Du, L., Mantel, R.J. and Schuur, P.C. (2005), "Mathematical model for warehouse design and product allocation", International Journal of Production Research, Vol. 43 No. 2, pp. 327-338.

Horta, M., Coelho, F. and Relvas, S. (2016), "Layout design modelling for a real world just-in-time warehouse", Computers \& Industrial Engineering, Elsevier Ltd, Vol. 101, pp. 1-9.

Hwang, C.-L. and Yoon, K. (1981), Multiple Attribute Decision Making, Vol. 186, Springer Berlin Heidelberg, Berlin, Heidelberg, available at:https://doi.org/10.1007/978-3-642-48318-9.

Jadhav, J.R., Mantha, S.S. and Rane, S.B. (2014), "Exploring barriers in lean implementation”, International Journal of Lean Six Sigma, Vol. 5 No. 2, pp. 122148.

Kahraman, C. (Ed.). (2008), Fuzzy Multi-Criteria Decision Making, Springer US, Boston, MA, available at:https://doi.org/10.1007/978-0-387-76813-7.

Kasirian, M.N. and Yusuff, R.M. (2013), “An integration of a hybrid modified TOPSIS with a PGP model for the supplier selection with interdependent criteria", International Journal of Production Research, Vol. 51 No. 4, pp. 1037-1054.

Kilic, H.S., Durmusoglu, M.B. and Baskak, M. (2012), "Classification and modeling for 
in-plant milk-run distribution systems", International Journal of Advanced Manufacturing Technology, Vol. 62 No. 9-12, pp. 1135-1146.

de Koster, R., Le-Duc, T. and Roodbergen, K.J. (2007), "Design and control of warehouse order picking: A literature review", European Journal of Operational Research, Vol. 182 No. 2, pp. 481-501.

Laosirihongthong, T., Adebanjo, D., Samaranayake, P., Subramanian, N. and Boon-itt, S. (2018), "Prioritizing warehouse performance measures in contemporary supply chains", International Journal of Productivity and Performance Management, Vol. 67 No. 9, pp. 1703-1726.

Li, D., Zhao, L., Wang, C., Sun, W. and Xue, J. (2018), "Selection of China's imported grain distribution centers in the context of the Belt and Road initiative", Transportation Research Part E: Logistics and Transportation Review, Elsevier, Vol. 120 No. October, pp. 16-34.

Lim, M.K., Bahr, W. and Leung, S.C.H. (2013), "RFID in the warehouse: A literature analysis (1995-2010) of its applications, benefits, challenges and future trends", International Journal of Production Economics, Vol. 145 No. 1, pp. 409-430.

Lima Junior, F.R. and Carpinetti, L.C.R. (2015), "Uma comparação entre os métodos TOPSIS e Fuzzy-TOPSIS no apoio à tomada de decisão multicritério para seleção de fornecedores", Gestão \& Produção, Vol. 22 No. 1, pp. 17-34.

Liu, C.-L. and Lee, M.-Y. (2018), "Integration, supply chain resilience, and service performance in third-party logistics providers", The International Journal of Logistics Management, Vol. 29 No. 1, pp. 5-21.

Liu, C. chao, Niu, Z. wen, Chang, P.C. and Zhang, B. (2017), "Assessment approach to stage of lean transformation cycle based on fuzzy nearness degree and TOPSIS", International Journal of Production Research, Taylor \& Francis, Vol. 55 No. 23, 
pp. $7223-7235$.

Luo, H., Yang, X. and Wang, K. (2019), “Synchronized scheduling of make to order plant and cross-docking warehouse", Computers and Industrial Engineering, Elsevier, Vol. 138 No. October, p. 106108.

Malta, J. and Cunha, P.F. (2011), “A new approach for cost modelling and performance evaluation within operations planning", CIRP Journal of Manufacturing Science and Technology, Vol. 4 No. 3, pp. 234-242.

Melton, T. (2005), "The Benefits of Lean Manufacturing", Chemical Engineering Research and Design, Vol. 83 No. 6, pp. 662-673.

Mills-Harris, M.D., Soylemezoglu, A. and Saygin, C. (2007), “Adaptive inventory management using RFID data", The International Journal of Advanced Manufacturing Technology, Vol. 32 No. 9-10, pp. 1052-1052.

Moayed, F.A. and Shell, R.L. (2009), “Comparison and evaluation of maintenance operations in lean versus non-lean production systems", Journal of Quality in Maintenance Engineering, Vol. 15 No. 3, pp. 285-296.

Moretti, E. de A., Anholon, R., Rampasso, I.S., Silva, D., Santa-Eulalia, L.A. and Ignácio, P.S. de A. (2019), "Main difficulties during RFID implementation: an exploratory factor analysis approach", Technology Analysis \& Strategic Management, Taylor \& Francis, Vol. 31 No. 8, pp. 943-956.

Moura, R.A. (2005), Sistemas e Técnicas de Movimentação e Armazenagem de Materiais (Materials Handling), IMAM, São Paulo.

Ben Moussa, F.Z., De Guio, R., Dubois, S., Rasovska, I. and Benmoussa, R. (2019), "Study of an innovative method based on complementarity between ARIZ, lean management and discrete event simulation for solving warehousing problems", Computers \& Industrial Engineering, Elsevier, Vol. 132 No. March, pp. 124-140. 
Mustafa, M. (2015), A Theoretical Model of Lean Warehousing, Politecnico di Torino, available at:https://doi.org/10.6092/polito/porto/2588573.

Mustafa, M.S., Cagliano, A.C. and Rafele, C. (2013), “A Proposed Framework for Lean Warehousing", Pioneering Solutions in Supply Chain Performance Management: Concepts, Technologies and Applications, Hamburg.

Oláh, J., Karmazin, G., Pető, K. and Popp, J. (2018), "Information technology developments of logistics service providers in Hungary", International Journal of Logistics Research and Applications, Taylor \& Francis, Vol. 21 No. 3, pp. 332-344.

Panousopoulou, P., Papadopoulou, E.-M. and Manthou, V. (2012), “Cross - Docking A Successful Method in Warehouses: A Case Study of a 3PL Provider", 2nd International Conference on Supply Chains, Katerini.

Pereira, C.M., Anholon, R. and Batocchio, A. (2016), "Method proposition to set the pallet positions designated to fractioned picking orders in a warehouse", Revista Gestão Da Produção Operações e Sistemas, Vol. 11 No. 4, pp. 231-248.

Phogat, S. (2013), "an Introduction To Applicability of Lean in Warehousing", International Journal of Latest Research in Science and Technology, Vol. 2 No. 5, pp. 105-109.

Ponte, B., Costas, J., Puche, J., Pino, R. and de la Fuente, D. (2018), "The value of lead time reduction and stabilization: A comparison between traditional and collaborative supply chains", Transportation Research Part E: Logistics and Transportation Review, Elsevier, Vol. 111, pp. 165-185.

Rampasso, I.S., Anholon, R., da Silva, D., Ordóñez, R.E.C. and Quelhas, O.L.G. (2019), "Maturity analysis of manufacturing cells", Production Planning \& Control, Taylor \& Francis, Vol. 30 No. 15, pp. 1250-1264.

Rowley, J. (2000), The Principles of Warehouse Design, The Institute of Logistics \& 
Transport, Corby.

Salhieh, L., Altarazi, S. and Abushaikha, I. (2019), "Quantifying and ranking the "7Deadly' Wastes in a warehouse environment”, The TQM Journal, Vol. 31 No. 1, pp. $94-115$.

Shah, R. and Ward, P.T. (2007), "Defining and developing measures of lean production", Journal of Operations Management, Vol. 25 No. 4, pp. 785-805.

Sharma, S. and Shah, B. (2016), "Towards lean warehouse: transformation and assessment using RTD and ANP”, International Journal of Productivity and Performance Management, Vol. 65 No. 4, pp. 571-599.

Singh, R.K., Gupta, A., Kumar, A. and Khan, T.A. (2016), "Ranking of barriers for effective maintenance by using TOPSIS approach", Journal of Quality in Maintenance Engineering, Vol. 22 No. 1, pp. 18-34.

Sobanski, E.B. (2009), Assessing Lean Warehousing: Development and Validation of Alean Assessment Tool, Oklahoma State University.

Staudt, F.H., Alpan, G., Di Mascolo, M. and Rodriguez, C.M.T. (2015), "Warehouse performance measurement: A literature review", International Journal of Production Research, Taylor \& Francis, Vol. 53 No. 18, pp. 5524-5544.

Swart, A.D. (2015), The Current Understanding of Lean Warehousing Principles in a Third Party Logistics Provider in South Africa, University of the Witwatersrand.

Tajima, M. (2007), "Strategic value of RFID in supply chain management", Journal of Purchasing and Supply Management, Vol. 13 No. 4, pp. 261-273.

Thomas, L.M. and Meller, R.D. (2015), “Developing design guidelines for a case-picking warehouse", International Journal of Production Economics, Vol. 170, pp. 741762.

Tortorella, G., Giglio, R., Fettermmann, D.C. and Tlapa, D. (2018), "Lean supply chain 
practices: an exploratory study on their relationship", The International Journal of Logistics Management, Vol. 29 No. 3, pp. 1049-1076.

Venkateswaran, S., Nahmens, I. and Ikuma, L. (2013), "Improving healthcare warehouse operations through 5S", IIE Transactions on Healthcare Systems Engineering, Vol. 3 No. 4, pp. 240-253.

Villarreal, B., Arriaga, J., Cardenas, C., Rivera, J.P. and Campos, H. (2014), “Improving Agility in Distribution Operations", International Conference on Industrial Engineering and Operations Management, Bali.

Villarreal, B., Garza-Reyes, J.A., Kumar, V. and Lim, M.K. (2017), “Improving road transport operations through lean thinking: a case study", International Journal of Logistics Research and Applications, Vol. 20 No. 2, pp. 163-180.

de Visser, J. (2014), Lean in the Warehouse: Measuring Lean Maturity and Performance within a Warehouse Environment, Rotterdam School of Management.

Wamba, S.F., Coltman, T.R. and Michael, K. (2008), "RFID-enabled warehouse optimization: lessons from early adopters in the 3PL industry", International Conference on Information Systems ICIS2008, Paris, pp. 14-17.

Wang, H., Chen, S. and Xie, Y. (2010), “An RFID-based digital warehouse management system in the tobacco industry: A case study", International Journal of Production Research, Vol. 48 No. 9, pp. 2513-2548.

Zhang, G., Nishi, T., Turner, S.D.O., Oga, K. and Li, X. (2017), “An integrated strategy for a production planning and warehouse layout problem: Modeling and solution approaches", Omega, Elsevier, Vol. 68, pp. 85-94. 



\section{Appendix 1. Interview Guide}

Analysis of Lean Warehouse Practices Applied to Distribution Centers

Questions should be answered, considering whether the practice is applied at your management's distribution center and the way it is performed, its inherent benefits and difficulties. The practices to be evaluated are:

P1) Stream optimization and operational waste elimination via Value Stream Mapping (VSM) application

P2) Use of inventory management technologies (Barcode, WMS and RFID);

P3) Warehouse organization and 5S culture

P4) Layout Studies to Optimize Storage Spaces

P5) Standardized Picking Methods

Q6) Inventory management using ABC curve and other addressing techniques

P7) Application of Cross Docking Technique

P8) Application of Total Productive Maintenance (TPM) concepts

P9) Degree of employee involvement and satisfaction

P10) Structure, use of performance indicators (KPI) and visual management

P11) Quality culture and use of continuous improvement tools

P12) Suitability and degree of automation of warehouse equipment for productivity

1. Is operational waste analysis and mapping of non-value added activities performed using the Value Stream Mapping (VSM) tool? What is your execution routine?

2. Is distribution center inventory management performed through any system?

Are barcode or RFID tags used for product tracking?

3. Is the $5 \mathrm{~S}$ culture performed for the distribution center organization? Do employees practice all "S" in their work? 
4. Is the operational layout structured according to studies for route optimization, reduced travel waste and employee safety?

5. Does picking activity have any criteria in its execution? Have there been any studies to set the best standards for each order type?

6. Are distribution center items allocated to inventory according to any specific addressing criteria aimed at increasing order picking productivity?

7. Does this distribution center have Cross Docking operations? Is this process performed for specific order types?

8. Is equipment maintenance performed by applying the concepts of total productive maintenance (TPM)?

9. How are employees involved in improving distribution center processes? Is there a participation incentive program for improvement suggestions and recognition for performance?

10. Are there operational indicators (KPI) monitored in visual management frameworks exposed in the areas? How is this update routine and discussions about these indicators with the operational leadership?

11. Are quality tools applied for operational problem solving? Who runs these tools and which are the most applied tools?

12. Do you use technologies and / or equipment automation to increase productivity in this distribution center? Which are? 